\title{
Roots, Rights and Risk: Canada, Childhood and the COVID-19 Global Pandemic
}

\author{
Sarah Ciotti \\ Ph.D. Candidate, Department of Child and Youth Studies \\ Brock University \\ sc17kx@brocku.ca \\ Shannon A. Moore \\ Professor, Department of Child and Youth Studies \\ Brock University \\ smoore@brocku.ca \\ Maureen Connolly \\ Professor, Kinesiology \\ Brock University \\ mconnolly@,brocku.ca \\ Trent Newmeyer \\ Director, Centre for Women's and Gender Studies and Associate Professor, Sociology \\ Brock University \\ tnewmeyer@brocku.ca
}

\begin{abstract}
The COVID-19 global pandemic highlights pre-existing inequities as well as the challenge of ensuring the protection of children's human rights in countries like Canada that have ratified the United Nations Convention on the Rights of the Child. SARS-CoV-2, referred to as the 2019 novel Coronavirus disease or COVID-19, presents a significant threat to public health. Children, although generally considered low risk of experiencing serious complications of the disease, have been considerably impacted by COVID-19 government-sanctioned distancing measures. COVID-19 is a persistent public health threat, thus, the long-term consequences are largely unknown. This qualitative research study, a content analysis of online Canadian media reports of COVID-19 and children, engaged transdisciplinary social justice methodology, social constructions of childhood and the intersection of race, socio-economic status, gender, and disability. The findings suggest COVID-19 reinforces the impact of discrimination, social exclusion and economic disparity on equity-seeking young people and families in Canada.
\end{abstract}

Keywords: children's rights, covid-19, social exclusion, intersectionality 


\section{Background}

Coronaviruses are a classification of viruses known to cause illness in humans and in some animal species (Singhal, 2020). Originating in Wuhan China and discovered in December 2019, SARS-CoV-2, the 2019 novel Coronavirus disease (COVID-19), is a severe respiratory illness triggered by an extremely infectious viral infection (Huang et al., 2020; Shereen et al., 2020). This highly infectious disease created a global health crisis. As of October 6, 2021 the World Health Organization (WHO) reported 235,673,032 confirmed cases of COVID-19 globally, with 4,814,651 confirmed deaths. The Government of Canada reported 1,643,420 cases of COVID-19 with 1,573,010 resolved and 28,050 deaths as of October 5, 2021. The pandemic varied in terms of its impact. Older adults and those with underlying health conditions were most likely to experience complications including death (Yang et al., 2020). Children under the age of 18 , accounted for only $2 \%$ of severely affected patients (Molloy \& Bearer, 2020). The consequences of infection varied significantly by age and health status.

The COVID-19 global pandemic highlights pre-existing inequities in equity-seeking communities as well as the challenge of ensuring children's human rights, as articulated in the United Nations Convention on the Rights of the Child (CRC) (1989), are protected. "Under the United Nations Convention on the Rights of the Child, like all signatories, Canada is obligated legally to take measures to increase public awareness of children's rights as described in the Convention" (Covell \& Howe, 1999, p.171). The effects of the COVID-19 global pandemic extend beyond the immediate risk to public health. Government-sanctioned distancing measures restricted interpersonal contact to "stop the spread" (Government of Ontario, 2020) and reduce potential exposure and transmission of the disease (Shereen et al., 2020) including at some points, prohibiting social gatherings outside of one's household, forced school closures and the transition to remote learning, and cancelled community programs. The full consequences of these restrictions are influenced by the intersection of social class, race, gender, disability, and citizenship.

Coronaviruses do not discriminate. As the World Health Organization (WHO) asserted in an August 25, 2020 Facebook post, "anyone can contract \#coronavirus regardless of race, gender, and or other personal qualities." Nevertheless, a Toronto Public Health (2020) report identified that racialized people represented a disproportionate number of confirmed COVID-19 cases in the city (Seucharan \& Bascaramurty, 2020). Perhaps unsurprising, Toronto, arguably Canada's most diverse and multicultural city, reported racial inequality with respect to the impact of the COVID-19. Albeit, viruses do not discriminate, however, people do: equityseeking groups across Canada continue to emphasize the need for social justice and improved social conditions for those traditionally under-represented and marginalized.

Simultaneously, racial justice was at the forefront of social discourse in the spring and summer of 2020 (early in to the COVID-19 lockdowns). Sparked by the May 25, 2020 police killing of George Floyd in the United States, citizens and activists across the globe initiated virtual and in-person protests opposing anti-black racism and supporting the Black Lives Matter 
movement (Altman, 2020; Gottbrath, 2020; Silverstein, 2021). Increased attendance at racial justice protests may partially be attributed to the detrimental financial consequences of the pandemic and increased medica coverage including positive social media coverage of the movement (Arora, 2020). Meanwhile, on Canadian soil, some politicians, including the Premier of Quebec François Legault, were quick to dismiss the presence of systemic racism (Loewen, 2020). In spite of this denial, social justice advocates, activists, and members of racialized communities across the country continued to bring to light issues of persistent and systemic racial discrimination. Another flagrant example of racial discrimination in Canada was the death of Joyce Echaquan, an Indigenous mother of seven who died in hospital on September 28, 2020 after seeking treatment for stomach pains (Lowrie \& Malone, 2020). Echaquan live-streamed on social media the abusive and deplorable treatment she received in hospital moments before her death. The video showed Echaquan suffering in pain as health care workers and hospital staff taunted and hurled insults at her. The Prime Minister of Canada, Justin Trudeau, was quick to denounce the treatment of Echaquan calling the treatment of her an example of "the worst form of racism" (Gilmore, 2020). Nevertheless, Echaquan's death draws attention to contemporary health inequity and violence against Indigenous women in Canada and their position "outside of the conventional boundaries of privileged femininity" (Morton, 2016, p. 303). In recognition of prevailing social inequity, social justice movements emerged from the backdrop of the pandemic through increased media reporting of racism and discrimination (Altman, 2020; Gottbrath, 2020; Silverstein, 2021). Subsequently, this brought increased social awareness of social justice tensions and reinforced government decisions to prioritize social welfare interventions targeting marginalized populations including, financial resources (the Canadian Emergency Response Benefit), housing resources (rent level freezes and eviction bans), and health resources (prioritizing vaccinations for adults in Indigenous communities) in addition to increased opportunities civic engagement for youth (Baskin-Sommers, 2021).

In Canadian media, reporting of human rights in relation to the COVID-19 pandemic focused on how emergency measures such as masks mandates (Yuen, 2020; Carter, 2020; Richardson, 2020), mobile contract tracing applications (Ho \& Singh, 2020), and lockdowns (Raymond, 2020) infringed on individual rights and freedoms. These media reports highlight the challenges faced by democratic governments in implementing public health strategies that balance individual rights and communal health (Nay, 2020). Compliance and resistance to government-sanctioned COVID-19 protocols must be framed with a broader socio-political and socio-cultural context. In their investigation of the impact of cultural variance (individualism vs collectivism) on the susceptibility to COVID-19 outbreaks across countries, Maaravi et al. (2021) found that countries that valued individualism over collectivism had higher COVID-19 cases and higher rates of mortality. Prevailing social conventions, including the prioritization of individual versus collective rights and responsibilities, are driven by dominant social values and reflect existing power structures. The pandemic brought to light which rights were most valued as well as the unequal distribution of power in Canadian society. 
Children's voices were marginalized in Canadian media during the COVID-19 global pandemic, their lived experiences were reported and analyzed through an adult-centric lens. A reflection of the social construction of childhood in Canada, childhood and children's roles are understood and contextualized by adults placed in positions of power and authority over them. Contemporaneous research on children's health emphasizes children as agents in their health care (Spencer et al., 2020). We argue that to fully implement a human rights framework, children's participation is imperative. As Crenshaw (1991) boldly asserts, "tokenistic, objectifying, voyeuristic inclusion is at least as disempowering as complete exclusion" (p. 1261). Child participation necessitates that adults attend to children when they communicate their views (Masschelein \& Quaghebeur, 2005). Importantly, "if we sincerely value the views of young people then we understand that their dignity, voice, and capacity for free will choice are all inherent birthrights, not something that is earned" (Moore, 2018, p. 474). The privileging of specific 'voices' remains a prominent focus in the social constructions of childhood (Prout \& James, 1997). In Canada's multicultural landscape, childhood is not hegemonic: children's experiences are not universal and "claims about identity and culture are framed by cultural relativism that sees culture as discrete, bounded and contending for positions on the multicultural Canadian stage" (Yon, 2000, p.37). As outlined in the WHO's 2008, Global Commission on the Social Determinants of Health, public health must be understood in terms of the broader social conditions and systems which create health inequities. With regard to children's health, pediatric guidelines have recognized the role of social determinants of health for over 25 years (Brochier et al., 2020). Effectively, the COVID-19 pandemic should be evaluated from this perspective, just as childhood must be understood in cultural context, given that, "childhoods across cultures vary dramatically in content and experience" (Chin, 2003, p.309). We acknowledge that Canada's population is diverse and nonhomogeneous; nonetheless, it is prudent to examine media reporting of childhood and the COVID-19 global pandemic in order to understand how children's rights are conceptualized across the country during that time period.

For the purposes of this paper, child rights are understood through the lens of the United Nations Convention on the Rights of the Child (CRC) (1989). The CRC is one of the world's most rapidly (Nguyen \& Mitchell, 2019) and widely ratified conventions globally and may be understood as an umbrella treaty that has informed standards for legislation, policy, and practice with young people under the age of 18 . Within this convention, four central principles compel countries that have ratified it, such as Canada, to ensure that young people are free from discrimination (Article 2); have their best interests considered in all decisions (Article 3); are able to grow and develop safely and in the best of physical and mental health (Article 6); and are able to participate fully and age-appropriately as full citizens in issues that affect them (Article 12; also Moore and Mitchell, 2007a, 2007b). These concepts also frame all domestic reports to the UN Committee on the Rights of the Child and are vital in understanding how all the treaty's remaining provisions were drafted.

This qualitative research study utilizes content analysis as the primary method (Macnamara, 2005; Babbie, 2004; Haller, 2010). It explores how children's rights are portrayed 
in Canadian online media reporting of childhood and the COVID-19 pandemic between March 12, 2020 and August 11, 2020. Analyzing representations of childhood in popular media provides insight into how children's rights are conceptualized in a society. The media has a substantial influence on shaping and informing public perception. Social media and the internet have been instrumental in increasing the accessibility of free information sharing amongst localized and global citizens. However, these platforms have also given rise to the spread of 'fake news' and have created challenges for consumers of the medium to critically examine and evaluate the reliability of information presented (Lazaroiu, 2014; Waldrop, 2017; Merchant \& Asch, 2018). In examining children's rights in Canada during the COVID-19 pandemic, we have been guided by the central question: how are children's rights conceptualized in Canada during the COVID-19 global pandemic? This research question is explored through the transdisciplinary social justice theoretical orientation (Moore, 2006 \& 2011) combining the conceptual frameworks of intersectionality (Crenshaw, 1989) and the social constructions of childhood (Prout \& James, 1997) which offers a deeper examination of the research problem being addressed.

\section{Social Location}

This research paper was constructed in real-time during the COVID-19 global pandemic. We explored the impact of COVID-19 on childhood, as information and knowledge about the disease were rapidly evolving. The full extent of the after-effects of the COVID-19 global pandemic has yet to be established. The authors of this paper come from a range of social locations and are all Canadian scholars, critically conscious of our privileged positioning. Two of the authors are working mothers with school-aged children who experienced first-hand the challenges of juggling parenting and child-care with career and professional responsibilities. We recognize that parents were tasked with researching and scrutinizing media reports, wading through sometimes conflicting information to make decisions regarding their children's education, health, and safety. Arguably, the sheer volume of online information and how it was presented heightened public fear and panic around COVID-19 and the unprecedented nature of the disease. Further, we understand the challenges faced by working parents, and in particular, working women attempting to juggle childcare responsibilities with professional obligations.

On a personal level, we have direct knowledge of the impact that COVID-19 distancing measures have had on young people including the loss of extra-curricular activities, the loss of social connections, celebrations, and events such as graduation and birthdays: their mobility and physical bodies restricted is not lost on us. We watched as children, including our own, were limited in their space and mobility. Alongside our youthful counterparts, we have all experienced the effects of distancing measures including changes to our professional and social lives. We recognize that for some individuals and groups, the losses were much greater, including loss of loved ones, employment, career opportunities, social connections, and income. As a result, we are acutely aware of our own historical and familial roots in settler-colonialism. This recognition of our privilege brings with it a heightened sense of social responsibility to advocate for 
members of equity-seeking communities impacted by structural injustices and disproportionately excluded from dominant social discourse and participation in socio-political domains.

\section{Theoretical Orientation}

This research is informed by a transdisciplinary social justice theoretical framework that seeks to increase equity and improve social conditions (Moore 2006 \& 2011; Moore \& Mitchell, 2008; Mitchell \& Moore, 2018). Transdisciplinary research involves community stakeholders to create new knowledge and address complex social problems (Choi \& Pak, 2006; Klein, 2015; Montuori, 2013) and "always involves the collaboration of multiple disciplinary...knowledge...to provide a holistic and synergistic approach to studying an issue or problem (Leavy, 2011, p. 29)". Transdisciplinarity research is useful in examining the issue of children's rights in the COVID-19 global pandemic because it seeks to create meaningful social change and address complex social problems through collaboration between disciplines and communities. This approach allows for a greater understanding of the social construction of childhood, and how children's rights were conceptualized in Canada during the COVID-19 pandemic. Children's experiences of the COVID-19 global pandemic are a highly pertinent and complex social phenomenon that would benefit from collaboration between researchers and children and youth participants.

\section{Conceptual Framework}

The conceptual framework of this paper combines intersectionality (Crenshaw, 1989) with social constructions of childhood (Prout \& James, 1997). According to Konstantoni \& Emejulu (2017), in childhood studies, intersectionality requires acknowledging "children as competent and knowing agents who we can, in solidarity, work with in social justice campaigns" (p.10). Carbado et al. (2013) describe intersectionality as a 'work-in-progress' and "suggests that we should endeavor, on an ongoing basis, to move intersectionality to unexplored places" (p.305). To conceptualize social constructions of childhood, it is necessary to explore the intersection of social class, race, gender, disability, and citizenship. As Goodley (2013) argues "discrimination is an increasingly complicated entanglement of disability, gender, sexuality, nation, ethnicity, age and class" (p. 641). Childhood is not universal; children from marginalized groups experience greater social exclusion as well as decreased opportunities for civic engagement and self-advocacy. According to Vrooman et al. (2015),

In general terms, social exclusion refers to people who experience an accumulation of disadvantage in the society in which they live. It may be regarded as a specific form of social inequality: socially excluded people lag behind in terms of what it takes to be a fully-fledged member of society (p.77).

Current dominant social and political systems are rooted in colonial and Eurocentric ideology which excludes and oppresses marginalized groups, particularly the historical and current discrimination of Black and Indigenous peoples in Canada (Maynard, 2017; Vowel, 2016). This 
discrimination is prevalent in all areas of social life including health care and social services (Williams \& Cooper, 2019), and has a profound impact on an individual's health and well-being. "Social exclusion is often mentioned as one of the social determinants of health" (O'Donnell et al., 2018, p.2), and "social exclusion is typically a profoundly painful experience" (Bennett, 2014, p.189). Families experiencing social isolation and exclusion before the COVID-19 pandemic are more vulnerable to adverse effects during and after.

The physical and mental health of young people are influenced by their adult caregivers and broader family systems. Kapilashrami \& Hankivsky (2018) argue, intersectionality "sheds light on the fact that individual and group inequalities are shaped by interactions between multiple sites and levels of power: institutions such as families, governments, laws and policies; structures of discrimination such as sexism, ableism, and racism; and broader processes of globalisation and neoliberalism" (p. 2589). Intersectional awareness provides additional insight into the ways in which young people are both directly and indirectly impacted by family stressors, including the stress experienced by their adult-caregivers (Prime et al., 2020). During the COVID-19 pandemic, Canadian child welfare agencies raised concerns in the media that child abuse and neglect reporting significantly declined (Pickel, 2020; Seatle, 2020; Baldwin, 2020). This decline could be attributed to COVID-related school and childcare closures. This represents a gap in the current literature, suggesting a need for further research exploring the relationship between COVID-19 and child abuse and neglect. Given the lack of connection to the community that can act as a protective factor for some children and young people, it is a fair supposition that COVID-19 quarantine measures might relate to child abuse and neglect reporting. Children most adversely impacted by COVID-19 came from families with disproportionately negative health and social outcomes before the pandemic (Sharafdin, 2020; Singh et al., 2020).

In addition to school closures, children, youth, and families saw the cancellation of community-based programs. For some children and youth, particularly those who are underresourced, community-based programs are a significant source of support in the form of mental health services, developmental services, nutrition, physical and social programs. This includes school-provided social assistance (The Lancet, 2020). Engagement in extra-curricular activities, including community-based arts, cultural and recreational programs, are central in children's rights. The Convention on the Rights of the Child, Article 31, identifies children's right to play, and specifies that "every child has the right to rest and leisure, to engage in play and recreational activities appropriate to the age of the child and to participate freely in cultural life and the arts." Community participation is important to the well-being of young people. The Search Institute (2020) asserts that relationships and community support are critical in child and youth development. If anything, the importance of community connection is amplified in a public health crisis; however, as a result of government efforts to contain the spread of COVID-19, children and youth saw a decreased connection with their community and a reduction in social and educational supports. 


\section{Methodology}

This qualitative research study is a secondary analysis of data from a larger qualitative research study of COVID-19 and childhood that focused on child and adolescent health. We reevaluated the data set through the lens of children's rights. As previously discussed, this study engages content analysis to critically evaluate online Canadian media sources (Macnamara, 2005; Babbie, 2004; Haller, 2010). To limit community contact and minimize the risk of COVID-19, this analysis is limited to Canadian media reports accessible via online databases. We searched google and Facebook online databases for the following terms: "COVID-19," "childhood" and "Canada." Non-Canadian media, anecdotal websites, and websites that did not contain COVID-19 related information were excluded from this study. Table 1.0 outlines the sources of data collected which include 70 online Canadian news media reports of COVID-19 and childhood obtained from 17 different regional and national Canadian news media outlets from large well-established publications, small community-based publications as well as publicly and privately funded sources.

Table 1.0

Data Sources

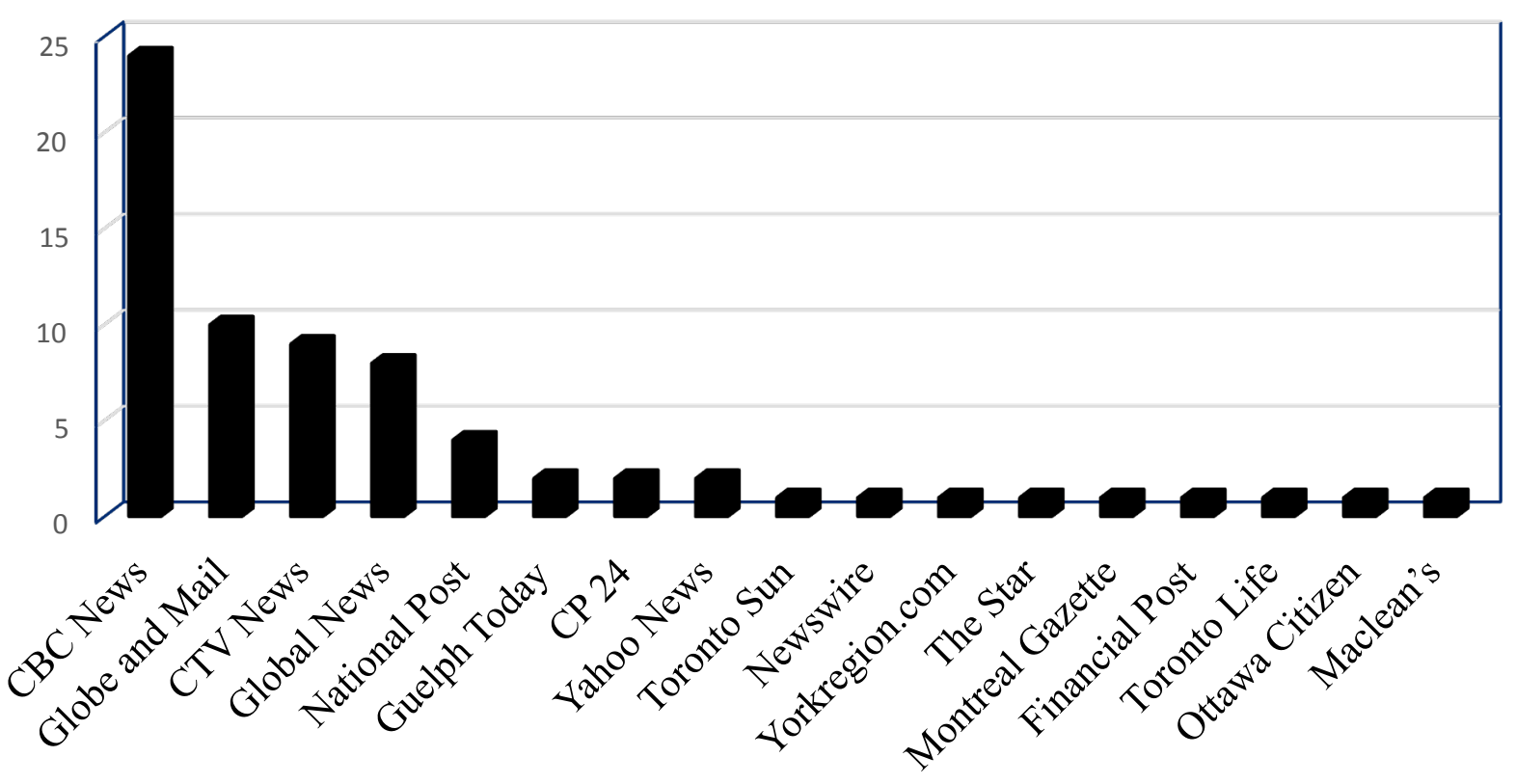

\section{Findings}

This empirical research found four main themes emerging from the data analysis. The analysis draws attention to the significance of these themes as a reflection of how children's rights were conceptualized in the COVID-19 global pandemic. These themes are: children's 
occupation of public space, children's educational rights, children's economic rights, and children's employment rights. Children and childhood are often described in relation to adults however, it is important to acknowledge children's rights as separate and distinct. Young people are distinctively impacted by COVID-19: if not directly by contracting the disease, then from the resulting social and structural changes.

\section{COVID-19: Children's Spaces and Children's Rights}

This global health crisis not only exposed the fragile nature of the Western, neo-liberal idea of progress as never-ending growth but also unveiled the contrast between its protectionist construction of childhood and the precarious nature of children's rights. At the height of the pandemic, the spaces that children and youth were allowed to occupy became exceptionally small: local, provincial, and federal governments limited access to public spaces, including those traditionally marked for childhood. Figure 1.0, a photograph of a children's play structure in a public park in Guelph, Ontario, represents how children's spaces were redefined in the COVID19 pandemic.

Figure 2.0

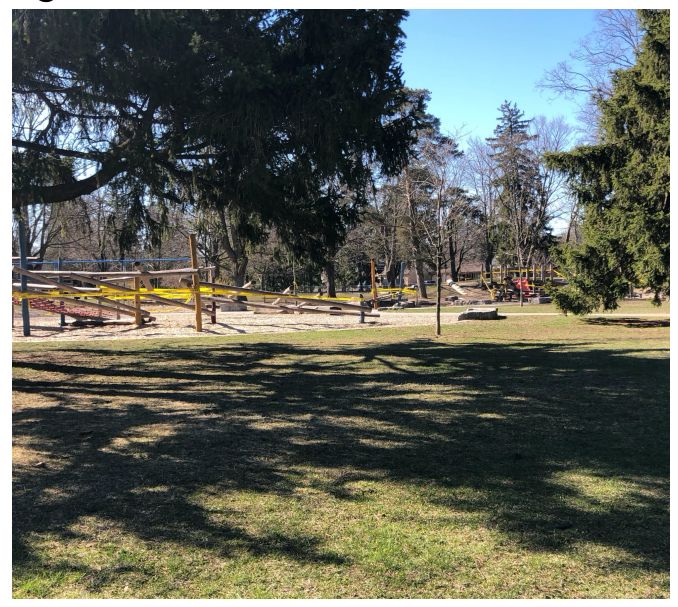

Exhibition Park, Guelph, Ontario, Canada dated April 25, 2020

The photograph demonstrates that spaces that were specifically designed for children were restricted by government agencies (in this case, the City of Guelph parks department). Notable is the appearance of yellow 'caution tape' that is typically used by police services at crime scenes when investigations are taking place and by developers on construction sites when repairs are taking place: the presence of which signals access has been restricted to the area. Commonly, this object is used to manage risk and liability by marking these spaces as 'out of bounds.' In this case, the tape was intended to renegotiate previously established boundaries of childhood space in the community. Playground spaces, designed for children's use, were restricted at the peak of government-sanctioned lockdowns in an effort to curtail further community spread of the disease. As research on the spread of COVID-19 evolved, governments deemed outdoor spaces 
lower-risk and encouraged citizens to utilize outdoor spaces in order to maintain their physical and mental health while continuing to avoid indoor social gatherings. Barad (2003) argues "the world is a dynamic process of intra-activity in the ongoing reconfiguring of locally determinate causal structures with determinate boundaries, properties, meanings, and patterns of marks on bodies" (p.817). Engagement and compliance with community-based social distancing were established and enforced by adults and excluded the input of young people. Although children and youth themselves were at a low-risk of severe illness and death, as potential vectors, their movement was restricted to prevent further community spread of COVID-19 (Balasubramanian et al., 2020) thereby justifying temporary limitations to their rights and freedoms in favour of collective safety. However, in fully implementing a children's rights framework, young people must be afforded opportunities to participate beyond the parameters set out for them by adults (Prout \& James, 1997; Lee, 2001). Awareness of intersectionality (Crenshaw, 1989) and social constructions of childhood (Prout \& James, 1997) offer additional context as to how these parameters are established and enforced. As Kennelly (2011) points out, young people from racialized groups and lower socioeconomic status are subjected to increased scrutiny from the state by way of police surveillance that restricts their social and political mobility and subsequent opportunities for civic engagement. Young people's mobility was restricted during the COVID19 pandemic, an authoritative and paternalistic decision justified by governments to prevent significant public health risks. The importance of these spaces for children's growth, development and well-being, and the potential impacts of restricting access to these spaces came secondary to the measures aimed at stopping the community spread of the virus.

COVID-19 has shone a spotlight on the flaws in Canada's neo-liberal, capitalist policies. The endorsement of globalism and free trade, which envisions a borderless economic world where goods and services can move quickly and cheaply between countries, collapsed in the face of this pandemic: borders quickly went back up as countries began amassing health supplies including masks/personal protective equipment and vaccines (Abedi, 2020). Canada was challenged to find countries to supply critical health equipment and an inability to find manufacturers at home. On a national level, this health crisis brought attention to the fragility of Canada's capitalist economic system; quarantine measures resulted in mass unemployment which was particularly problematic given the Bank of Canada had been drawing attention to increases in household debt across the country in recent years (The Canadian Press, 2020). Many Canadians found themselves in precarious financial situations with little to no savings, high levels of debt, and a loss of income (Akin, 2020) making it difficult for individuals and families to financially cover their monthly expenses. As a result, the Government of Canada was compelled to act swiftly by implementing a temporary funding source called Canada Emergency Response Benefit (CERB) which offered a maximum of \$2000/month to those financially impacted by COVID-19 (Government of Canada, 2020). This response intentionally stopped short of a basic income supplement: temporary financial resources were intended to slow the economic effects of government-sanctioned distancing measures and made little effort to address the deeply entrenched systemic issues and cultural attitudes contributing to the rising household 
debt in the country (Poloz, 2018) which draws attention to pre-existing socio-economic challenges faced by many Canadian families prior to the pandemic. We argue that this inequity necessitates meaningful social change and suggest that change must begin with increased opportunities for participation and civic engagement and greater social, economic, and political inclusion. Mitchell \& Moore (2012) argue the "world society drifts dangerously toward 'neoliberal capitalist collapse'..." (p.1). They argue that, "any viable alternative paradigm may be undertaken within the transdisciplinary framework of active, participatory and inclusive expressions of child and youth citizenship" (p. 2). Equity-seeking groups have long sought representation and inclusion for all members of society: children, youth, and other groups whose voices have traditionally been marginalized; representation and inclusion are critical steps in the creation of meaningful social change.

\section{COVID-19: Children's Education and Children's Rights}

Community-based distancing measures significantly influenced education in Canada and throughout the globe. According to The Lancet, Child and Adolescent Health (2020) "by midApril, $86 \%$ of the world's children - more than 1.4 billion in total—were out of school. When accounting for those unable to learn remotely without Internet access, $60 \%$ of primary schoolaged children worldwide and $86 \%$ in low-HDI countries are effectively out of education." Children's right to education, as addressed in the Convention on the Rights of the Child, Article 29 , must be adapted to the child's "personality, talents and mental and physical abilities to their fullest potential." In mid-March, as COVID-19 rates in Canada began to set off public health alarms, provincial governments grappled with decisions to close schools. Children and parents scrambled to adapt to online learning with little notice. Online learning required that children had access to the internet and technological devices like computers and tablets. The switch to a remote, online delivery model of education sparked conversations about inequity and the need for change in how education is administered. As D'Amore (2020) powerfully asserted, "school needs to be reimagined. The old 'normal' was already not working for so many students." Education, in the COVID-19 pandemic, was informed by the pre-existing educational model and roughly modified to be accessible in an online format. As children and families adapted to online learning, problems with its design were brought to the forefront including a failure to recognize children's unique learning needs resulting in "lackluster engagement from some students since schools closed in March" (Wong, 2020). This discourse points to problems in the current educational system and advocates for structural change.

In Canada, education falls under provincial and territorial jurisdiction: all provincial and territorial governments across the country closed schools because of COVID-19 and adopted standardized home-based learning curriculums (Ho, 2020; People for Education, 2020). Rather precipitously, and without consultation, young people were tasked with adapting to home-based educational formats and self-directed learning. Access to the internet and technological devices rendered critical and families without access to appropriate technology were marginalized by this change. The adapted format failed at addressing barriers to inaccessibility, as some students, 
particularly children with disabilities (Government of Ontario, 2020) and those from lower socio-economic households were left without access to the internet. Online learning, as structured in the COVID-19 pandemic, presented an impediment to the rights of children with disabilities given that, "according to the Convention on the Rights of the Child, Article 1, children with disabilities are entitled to all rights guaranteed to all children" (Walugembe et al., 2019 , p.192). For education to be meaningful for students, curriculum and pedagogy must be customized to a child's individual learning needs and be socially just and culturally responsive (Richards, Graber \& Woods, 2018). Changes to the learning environment must take into consideration the individual learning needs of all students.

\section{COVID-19: The Economy and The Rights of the Child}

The economic impact of COVID-19 dominated in Canadian media reports: the pandemic drew attention to the fragility of Canada's economic system. As Brown (2020) powerfully declared, "accumulating wealth and maintaining capitalism's health at the expense of other goals have dominated public discourse for nearly four decades. Maybe we're sick and tired enough now to think about something else." Two polarizing perspectives emerged: the first, an insistence on resuming previous economic activities across the country and the second, advocacy for social change which would address economic inequality. These perspectives were often guided by socio-political ideology, underscoring the intersection of media and politics.

The economic effects on children, parents, and families were not universal. COVID-19 presented employment challenges for working parents. These challenges were described in the context of employment rights. Some workplaces actively accommodated employees working remotely online from home while others, such as those in the services sector, were required to close temporarily or even permanently and therefore, were forced to lay off workers or eliminate jobs, drawing attention to issues of employment inequity across the country. Employment disparity encompasses the intersectionality of race, socio-economic status, gender, education, and disability. Discussions of the economic impact of COVID-19 and children centered on the impact of school and daycare closures on parental income and employment. As Gorman (2020) argues, "for the economy to reach its full potential, childcare must become universal." Child care has an impact on the Canadian economy in addition to family finances, particularly, for mothers, considering that childcare responsibilities are disproportionately shouldered by women (Stroh, 2020; Parmar, 2020; Alini, 2020). Working mothers are tasked with juggling their careers and parenting responsibilities and COVID-19 undeniably amplified this.

\section{COVID-19: Children as Essential Workers}

During the COVID-19 global pandemic some young people took on roles as essential workers in low-wage employment. As Subramanian (2020) points out, some young people went from their roles as students in the classroom to online learners and essential service workers, taking on employment in grocery stores and other low-wage retail jobs to fill COVID-19 related employment gaps. The Convention on the Rights of the Child, Article 32, describes children's 
right to protection from work that is harmful to their development. The harm to young essential service workers during the pandemic has yet to be established and defined. What is clear, according to the Government of Canada (2021), is that workers (young and old) working in businesses operating during the COVID-19 pandemic, are at increased risk of contracting COVID-19 from community spread, thus necessitating additional public health mandated occupational health and safety protocols. In spite of the increased stress and risk, young essential workers were still not viewed as active agents in their own right, employment issues and rights were primarily concerned with adult workers in Canadian media reporting: a reflection of the broader social construction of childhood. Routinely, young people are not consulted in decisions made on their behalf. In terms of the COVID-19 global pandemic, this translates to exclusion from dominant social institutions and spaces designed for them, including schools. This points to the hypocrisy that young people were denied access to certain spaces deemed "unsafe" such as school classrooms while at the same time performing critical roles in delivering essential services to their communities that increased their own risk of contracting the disease. Caputo (2017) argues, "participation requires exploring its nature as well as interrogating the related concepts of agency, power, and childhood...(it) compels questioning its conceptual basis, its purpose and intent, the power relations that enable and constrain children's and young people's engagement, and how, and under what circumstances, children and young people become involved in participatory processes" (p.77). During the pandemic, young people were welcomed into low-wage employment, often replacing higher-risk adults in low-wage, unskilled work, yet at the same time were denied rights of full-citizenship including opportunities for political and civic engagement.

\section{Limitations \& Recommendations}

Media reports are subject to interpretation. We attempted to access all available Canadian media content on childhood and COVID-19, however, the data is limited to information gathered from particular search engines and search terms employed. In consideration of public health guidelines during the COVID-19 pandemic, primarily, to limit non-essential trips to stores and businesses in order to prevent the spread of COVID-19, this paper is limited to content from Canadian media reports available online. COVID-19 remains a significant global concern and this study is inclusive of the information available at the time the data was collected. We acknowledge that advancements in COVID-19 research will endure long after the completion of this research study.

The results of this study highlight gaps in the current literature and opportunities for further research. To date, the COVID-19 pandemic has occurred contemporaneously alongside scholarly research, necessitating further investigation and evaluation of the full extent of its impact. Childhood and children's rights scholars must find opportunities to work collaboratively with young people. We advocate for qualitative research that emphasizes the experiences of young people from their own perspectives. Research that explores the impact of COVID-19 on children's rights is warranted. Any research focused on the results of COVID-19 on children should be developed in this collaborative spirit. 


\section{Conclusion}

The COVID-19 global pandemic has exposed social, health, economic, and structural inequities that existed in Canada's social systems before the global health crisis. These points of injustice are reinforced and indelibly linked to institutionalized racism and discrimination within the country's social and political systems. Canadians from equity-seeking communities experience systemic barriers and increased social exclusion in government, healthcare, education, and child welfare. Although all Canadian citizens were affected by the pandemic in some way, there were varying degrees of impact largely based on prior social, economic, and health status. The impact of COVID-19 has varied across social, racial, and economic demographics. The pandemic has had a crucial and distinctive impact on children and youth. Young people were excluded from making decisions about their safety, health, and well-being, and limited in their mobility and opportunities for social and political engagement. An erasure of children's rights discourses was evident in Canadian media reporting during the pandemic. This fact highlights how ideas of childhood and young people are social constructions driven by adults rather than through children's participation and involvement in issues that impact their well-being.

*Conflicts of interest: The authors have no conflicts of interest to disclose.

Sources of Funding: This research did not receive any specific grant from funding agencies in the public, commercial, or non-for-profit sectors.

\section{References}

Abedi, M. (2020, April 3). Coronavirus: Trump asks medical supply firm 3M to top selling N95 respirators to Canada. Global News. Retrieved from https://globalnews.ca/news/6772979/coronavirus-3m-n95-respirators-trump-Canada/

Akin, D. (2020, June 7). ANALYSIS: A looking coronavirus debt crisis could swamp Canadian households. Global News. Retrieved from https://globalnews.ca/news/7027309/coronavirus-debt-crisis-canada/

Alini, E. (2020, September 12). One-third of working moms mulled quitting their jobs due to COVID-19: survey. Global News. Retrieved from https://globalnews.ca/news/7328279/one-third-working-moms-quitting-covid-19prosperity-project/

Altman, A. (2020, June 4). Why The Killing of George Floyd Sparked an American Uprising. Time. Retrieved from https://time.com/5847967/george-floyd-proteststrump/

Arora, M. (2020, August 5). How the coronavirus pandemic helped the Floyd protests become the biggest in U.S. history. The Washington Post. Retrieved from https://www.washingtonpost.com/politics/2020/08/05/how-coronavirus-pandemichelped-floyd-protests-become-biggest-us-history/ 
Babbie, E. (2004). The practice of social research (10th ed.). Belmont, USA.

Thomson/Wadsworth.

Balasubramanian, S., Rao, N. M., Goenka, A., Roderick, M., \& Ramanan, A. V. (2020).

Coronavirus Disease 2019 (COVID-19) in Children - What We Know So Far and What We Do Not. Indian pediatrics, 57(5), 435-442.

Baldwin, D. (2020, May 7). Highland Shores CAS 'here to help' despite call decline amid pandemic. The Intelligencer. Retrieved from https:/www.intelligencer.ca/news/localnews/highland-shores-cas-here-to-help-despite-call-decline-amid-pandemic.

Barad, K. (2003). Posthumanist performativity: Toward an understanding of how matter comes to matter. Signs: Journal of Women in Culture and Society, 28(3): 801-831.

Baskin-Sommers, A., Simmons, C., Conley, M., Chang, S. A., Estrada, S., Collins, M., Pelham, W., Beckford, E., Mitchell-Adams, H., Berrian, N., Tapert, S. F., Gee, D. G., \& Casey, B. J. (2021). Adolescent civic engagement: Lessons from Black Lives Matter. Proceedings of the National Academy of Sciences of the United States of America, 118(41).

Bennett, M. (2014). Intergroup Social Exclusion in Childhood: Forms, Norms, Context, and Social Identity. Journal of Social Issues, 70(1), 183-195.

Brochier, A., Messmer, E., \& Garg, A. (2020). Physicians and Social Determinants of Health. JAMA, 324(12), 1215.

Brown, I. (2020, April 12). Your money or your life? Coronavirus-era economics makes us ask grim questions about how to value each other. The Globe and Mail. Retrieved from https://www.theglobeandmail.com/canada/article-your-money-or-your-life-coronavirusera-economics-makes-us-ask-grim/?fbclid=IwAR2uiiCMQVZrW1QUGQwGi6wb3RhzF-RfFCooHV3YDkHQzqDbq9QiBGH72s

Caputo, V. (2017). Children's participation and protection in a globalised world: Reimagining 'too young to wed' through a cultural politics of childhood. The International Journal of Human Rights, 21(1), 76-88.

Carbado, D. W., Crenshaw, K. W., Mays, V. M., \& Tomlinson, B. (2013).

INTERSECTIONALITY: Mapping the Movements of a Theory. Du Bois review: social science research on race, 10(2), 303-312.

Carter, A. (2020, September 28). Anti-masker broke quarantine to speak at Toronto anti lockdown protest after travelling to Europe. CBC News. Retrieved from https://www.cbc.ca/news/canada/toronto/toronto-anti-mask-chris-sky-quarantine-protest1.5741822

Chin, E. (2003). Children out of bounds in globalising times. Postcolonial Studies, 6(3), 309-325.

Choi, B. C. K., \& Pak, A. W. P. (2006). Multidisciplinarity, interdisciplinarity and transdisciplinarity in health research, services, education and policy: 1. Definitions, objectives, and evidence of effectiveness. Clinical \& Investigative Medicine, 29(6), 351364. 
Covell, K. \& Howe B. (1999). The impact of children's rights education: A Canadian study. The International Journal of Children's Rights, 7, 171-183.

Crenshaw, K.W. (1989). Demarginalizing the Intersection of Race and Sex: A Black Feminist Critique of Antidiscrimination Doctrine. University of Chicago Legal Forum, 139-168.

Crenshaw, K.W. (1991). Mapping the margins: Intersectionality, identity politics, and violence against women of color. Stanford Law Review, 1241-1299.

D’Amore, R. (2020, May 19). Can we really keep kids distant in school amid COVID-19? It won't be easy, experts say. Global News. Retrieved from https://globalnews.ca/news/6958387/coronavirus-canada-schools-reopening/

Gilmore, R. (2020, October 1). Groups call for action after dying Atikamekw woman subjected to 'the worst form of racism'. CTV News. Retrieved from https://www.ctvnews.ca/politics/groups-call-for-action-after-dying-atikamekw-womansubjected-to-the-worst-form-of-racism-1.5128941

Goodley, D. (2013). Dis/entangling critical disability studies. Disability and Society, 28(5), 631-644.

Gorman, M. (2020, June 9). Child-care providers hope COVID-19 leads to universal access in Nova Scotia. CBC News. Retrieved from https://www.cbc.ca/news/canada/novascotia/covid-19-daycare-childcare-universal-access-1.5603659

Gottbrath, L-W. (2020, December 31). In 2020, the Black Lives Matter movement shook the world. Aljazeera. Retrieved from https://www.aljazeera.com/features/2020/12/31/2020the-year-black-lives-matter-shook-the-world

Government of Canada. (2020). Canadian Emergency Response Benefit. Ottawa, ON: Government of Canada. Retrieved from https://www.canada.ca/en/services/benefits/ei/cerb-application.html

Government of Canada. (2021). How businesses and employees can stay safe while operating during COVID-19. Retrieved from https://www.canada.ca/en/publichealth/services/diseases/2019-novel-coronavirus-infection/prevention-risks/guidanceworkplaces-covid-19.html

Government of Ontario. (2020, April 10). COVID-19: Stop the spread. Toronto, ON: Government of Ontario. Retrieved from https://www.ontario.ca/page/covid-19-stopspread

Government of Ontario. (2020, August 21). COVID-19 barriers for students with disabilities and recommendations. Toronto, ON. Retrieved from https://www.ontario.ca/page/covid-19-barriers-students-disabilities-andrecommendations

Haller, B. (2010). Representing disability in an ableist world: essays on mass media. Louisville, USA. The Advocado Press. 
Ho, S. \& Singh, M. (2020, October 14). COVID-19 eroding global internet freedom, Canada among the freest, report says. CTV News. Retrieved from https://www.ctvnews.ca/scitech/covid-19-eroding-global-internet-freedom-canada-among-the-most-free-report-says1.5145180

Kapilashrami, A., \& Hankivsky, O. (2018). Intersectionality and why it matters to global health. Lancet (London, England), 391(10140), 2589-2591.

Kennelly, J. (2011). Policing young people as citizens-in-waiting. The British Journal of Criminology, 51(2), 336-354.

Klein, J. T. (2015). Discourses of transdisciplinarity: Looking back to the future. Futures, 65, 10-16.

Konstantoni, K., \& Emejulu, A. (2017). When intersectionality met childhood studies: the dilemmas of a travelling concept. Children's Geographies, 15(1), 6-22.

Land, N., Gulamhusein, S., Scott, A., \& Coon, E. (2018). Transdisciplinary Conversations in Child and Youth Care. World Futures, 74(7-8), 572-594.

Leavy, P. (2011). Essentials of transdisciplinary research: using problem-centered methodologies. Walnut Creek, USA. Left Coast Press.

Lee, N. (2001). Childhood and Society: Growing Up in an Age of Uncertainty. Maidenhead, Berkshire, United Kingdom. Open University Press.

Loewen, C. (2020, June 2). As premier denies systemic racism, black Quebecers point to them lived experience. CBC News. Retrieved from https://www.cbc.ca/news/canada/montreal/systemic-racism-police-brutality-quebec1.5594071

Lowrie, M. \& Malone, G. (2020, October 2). Joyce Echaquan's death highlights systemic racism in health care experts say. City News. Retrieved from https://toronto.citynews.ca/2020/10/02/joyce-echaquans-death-highlights-systemicracism-in-health-care-experts-say/

Macnamara, J. (2005). Media content analysis: Its uses, benefits and best practice methodology. Asia Pacific Public Relations Journal, 6, 1-34.

Maaravi, Y., Levy, A., Gur, T., Confino, D., \& Segal, S. (2021). "The Tragedy of the Commons": How Individualism and Collectivism Affected the Spread of the COVID-19 Pandemic. Frontiers in public health, 9, 627559.

Masschelein, J., \& Quaghebeur, K. (2005). Participation for Better or for Worse? Journal of Philosophy of Education, 39(1), 51-65.

Maynard, R. (2017). Policing Black Lives: State Violence in Canada from Slavery to the Present. Black Point, Canada. Fernwood Press.

Mitchell, R.C. (2010). Who's Afraid Now? Reconstructing Canadian Citizenship Education Through Transdisciplinarity. Review of Education, Pedagogy \& Cultural Studies, 32(1), 37-65. 
Mitchell, R. C., \& Moore, S.A. (2012). Politics, participation \& power relations: transdisciplinary approaches to critical citizenship in the classroom and community. Boston, USA. Sense Publishers.

Molloy, E. J., \& Bearer, C. F. (2020). COVID-19 in children and altered inflammatory responses. Pediatric Research, 88, 340-341.

Montuori, A. (2013). The Complexity of Transdisciplinary Literature Reviews. Complicity: An International Journal of Complexity and Education, 10(1), 45-55.

Moore, S.A. \& Mitchell, R. C. (2008). Power, pedagogy and praxis: social justice in the globalized classroom. Boston, USA. Sense Publishers.

Moore, S.A. (2006). Transdisciplinary critical multicultural pedagogy in Canadian higher education. In D. Zinga (Ed.), Navigating Multiculturalism (126-139). Cambridge, United Kingdom. Scholars Press.

Moore, S.A. (2011). Preface: Social justice in child, youth and family studies. International Journal of Child, Youth and Family Studies, 2 (3/4), 353-360.

Moore, S.A. (2018). Radical Listening: Transdisciplinarity, Restorative Justice and Change. World Futures, 74, 471-489.

Moore, S.A. \& Mitchell, R.C. (2007a). Rights Based Restorative Justice: Towards Critical Praxis with Young People in Conflict with the Law. In Ang, A., Delens-Ravier, A., Delplace, M., Herman, C.,Reynaert, D., Staelens, V., Steel, R. and Verheyde, M. (eds) The UN Children's Rights Convention: Theory Meets Practice. Proceedings of the International Interdisciplinary Conference on Children's Rights (549-564). Mortsel, Belgium. Intersentia.

Moore, S.A. \& Mitchell, R.C. (2007b). Herstelrecht volgens demensenrechtenprincipes (or 'Rights based Restorative Justice'). Het Tijdschrift voor Jeugdrecht en Kinderrechten (or TJK - Flemish Journal for Youth and Children's Law) 5(4): 251-59.

Morton, K. (2016). Hitchhiking and Missing and Murdered Indigenous Women: A Critical Discourse Analysis of Billboards on the Highway of Tears. The Canadian Journal of Sociology / Cahiers Canadiens De Sociologie, 41(3), 299-326.

Nay, O. (2020). Can a virus undermine human rights? The Lancet Public Health, 5(5), 238239.

Nguyen, X.T. \& Mitchell, C. (2019). Disability, Intersectionality, and Struggles Over Social Justice: Reframing Debates over Children's Rights. Canadian Journal of Children's Rights, 6(1).

O'Donnell, P., O'Donovan, D., \& Elmusharaf, K. (2018). Measuring social exclusion in healthcare settings: a scoping review. International journal for equity in health, 17(1), 15.

Parmar, T. (2020, September 23). Working mothers feeling the effects of COVID-19 pandemic stress, fatigue, burnout. CityNews. Retrieved from https://www.citynews1130.com/2020/09/23/working-mothers-feeling-impacts-covid/ 
People for Education. (2020, May 8). Tracking Canada's education systems' response to COVID-19. Retrieved from https://peopleforeducation.ca/our-work/tracking-canadaseducation-systems-response-to-covid-19/

Pickel, J. (2020, April 28). 'A significant worry': Family \& Children's Services concerned about drop in referrals. CTV News. Retrieved from https://kitchener.ctvnews.ca/a-significantworry-family- -s-services-concerned-about-drop-in-referrals1.4916473 ? cache $=\% 3$ FclipId $\% 3$ D 68596

Poloz, S. (2018, May 1). Canada's Economy and Household debt: How Big is the Problem? Bank of Canada. Retrieved from https://www.bankofcanada.ca/2018/05/canada-economyhousehold-debt-how-big-the-problem/

Prime, H., Wade, M., \& Browne, D. T. (2020). Risk and resilience in family well-being during the COVID-19 pandemic. The American psychologist, 75(5), 631-643.

Prout, A. \& James, A. (1997). A New paradigm for the Sociology of Childhood? Provenance, Promise and Problems. In A. James and A Prout (eds) Constructing and Reconstructing Childhood: Contemporary Issues in the Sociological Study of Children (7-34). Basingstoke, United Kingdom. Falmer Press.

Raymond, T. (2020, September 30). Ontario doctors sign letter to Premier advising against sweeping lockdowns. CTV News. Retrieved from https://ottawa.ctvnews.ca/ontariodoctors-sign-letter-to-premier-advising-against-sweeping-lockdowns-1.5126193

Richards, K. A. R., Graber, K. C., \& Woods, A. M. (2018). Using theory to guide research: Applications of constructivist and social justice theories. Kinesiology Review, 7(3), 218225.

Richardson, G. (2020, October 13). Doug Ford blasts anti-maskers who targeted his home on Thanksgiving weekend. CTV News. Retrieved from https://ottawa.ctvnews.ca/dougford-blasts-anti-maskers-who-targeted-his-home-on-thanksgiving-weekend-1.5143598

Robinson, J. (2008). Being undisciplined: transgressions and intersections in academia and Beyond. Futures, 40, 70-86.

Seatle, P. (2020, April 29). Concerns raised after child abuse calls drop dramatically in the GTA. CityNews. Retrieved from https://toronto.citynews.ca/2020/04/29/child-abusecalls-drop-gta-coronavirus/

Sharafdin, D. (2020, September 28). Children around the world are being adversely affected by COVID-19. The Star. Retrieved from

https:/www.thestar.com/opinion/letters_to the editors/2020/09/26/children-around-theworld-are-being-adversely-affected-by-covid-19.html

Silverstein, J. (2021, June 4). The global impact of George Floyd: How Black Lives Matter protests shaped movements around the world. CBS News. Retrieved from: https://www.cbsnews.com/news/george-floyd-black-lives-matter-impact/

Singh, S., Roy, D., Sinha, K., Parveen, S., Sharma, G., \& Joshi, G. (2020). Impact of COVID-19 and lockdown on mental health of children and adolescents: A narrative review with recommendations. Psychiatry research, 293, 113429. 
Singhal T. (2020). A Review of Coronavirus Disease-2019 (COVID-19). Indian Journal of Pediatrics, 87(4), 281-286.

Spencer, G., Fairbrother, H., \& Thompson, J. (2020). Privileges of Power: Authenticity, Representation and the "Problem" of Children's Voices in Qualitative Health Research. International Journal of Qualitative Methods.

Stroh, P. (2020, August 17). Pandemic threatens to wipe out decades of progress for working mothers. CBC News. Retrieved from https://www.cbc.ca/news/business/womenemployment-covid-economy-1.5685463

Subramanian, S. (2020, June 11). The COVID-19 pandemic is remapping childhood - and the effects may linger. Macleans. Retrieved from https://www.macleans.ca/society/health/covid-19-pandemiccoronavirus-canada-children-effects/

The Canadian Press. (2020, May 14). Bank of Canada warns in report of business, household debt from COVID-19. National Post. Retrieved from https://nationalpost.com/pmn/news$\mathrm{pmn} /$ canada-news-pmn/bank-of-canada-warns-of-excess-business-household-debt-fromcovid-19

The Search Institute. (2020). Developmental Relationships the Gateway to Building Assets. The Search Institute. Retrieved from https://www.search-institute.org/ourresearch/development-assets/developmental-relationships-gateway-building-assets/

The Lancet Child \& Adolescent Health. (2020). Pandemic school closures: risks and opportunities. The Lancet Child \& Adolescent Health, 4(5), 341.

The Lancet Child Adolescent Health (2020). Prioritising children's rights in the COVID-19 response. The Lancet. Child \& adolescent health, 4(7), 479.

The World Health Organization. (2008). Commission on Social Determinants of Health, 20052008. Retrieved from https://www.who.int/teams/social-determinants-of-health/equityand-health/commission-on-social-determinants-of-health

United Nations. (1989). Convention on the Rights of the Child. New York: United Nations.

Vowel, C. (2016). Indigenous Writes: A guide to First Nations, Métis \& Inuit Issues in Canada. Winnipeg, Canada. Portage \& Main Press.

Vrooman, J., Hoff, S., \& Guiaux, M. (2015). Descendants of Hardship: Prevalence, Drivers and Scarring Effects of Social Exclusion in Childhood. Social Inclusion, 3(4), 76-97.

Walugembe, P., Wamala, R. \& Misindle, C. (2019). The Rights of Children with Disabilities and the Influence of Disability on Household Vulnerability: A Case of Vulnerability in Rural Uganda. Canadian Journal of Children's Rights 6, (1), 169-195.

Webster, F., Rice, K., \& Sud, A. (2019). A critical content analysis of media reporting on opioids: The social construction of an epidemic. Social Science \& Medicine, 112642.

Williams, D. R., \& Cooper, L. A. (2019). Reducing Racial Inequities in Health: Using What We Already Know to Take Action. International journal of environmental research and public health, 16(4), 606. 
Wong, J. (2020, June 5). What might K-12 schools look like in the fall? Depends where you are, educators say. CBC News. Retrieved from https://www.cbc.ca/news/canada/schoolsreopening-planning-fall-1.5597781

Yang, J., Zheng, Y., Gou, X., Pu, K., Chen, Z., Guo, Q., Ji, R., Wang, H., Wang, Y., \& Zhou, Y. (2020). Prevalence of comorbidities and its effects in coronavirus disease 2019 patients: A systematic review and meta-analysis. International journal of infectious diseases: IJID: official publication of the International Society for Infectious Diseases, 94, 91-95. Advance online publication.

Yuen, J. (2020, July 6). The psychology behind anti-maskers. Toronto Sun. Retrieved from https://torontosun.com/news/local-news/the-psychology-behind-antimaskers

Yon, D. (2000). Elusive Cultures. Albany, USA. SUNY. 